\title{
Refugees with Disabilities: A Human Rights Perspective
}

\author{
Lina Anani
}

\begin{abstract}
This paper will provide a preliminary survey of the evolution and positioning of disability rights as human rights and the discrepancy between Canadian resettlement policies with regard to refugees and Canada's rhetoric with regard to persons with disabilities. Some of the activities of the disability rights movements are outlined and significant achievements at the international level through the United Nations are examined. Similar to the women's human rights movement, disability rights are also emerging from the margins towards the mainstream of human rights discourse. Canada's legislation and policies towards persons with disabilities have mirrored these developments in providing protection. However, for refugees with disabilities the benefits seem minimal. In fact, while proclaiming the rhetoric of disability rights to its own citizens, Canada has implemented policies which are discriminatory towards refugees with disabilities. Canada's overseas resettlement selection criteria is at odds with its domestic and international positions regarding the human rights of persons with disabilities.
\end{abstract}

\section{Résumé}

Cetarticledonneraunaperçupréliminaire desdiversmouvementsquimilitentpourles droitsdes handicapés, l'évolution des droits deshandicapéscommedroitsdel'hommeet la divergence qui existe entre la politique canadienneen matièred'établissementdes réfugiésetlarhétoriqueduCanadaencequi concerne les personnes handicapées. Quelques-unesdesactivitésdumouvement pourlesdroitsdeshandicapéssontmisesen

Lina Anai, who lives with a disability, is completingher MAin Women's Studies atYork University. Her research interests include gender and genocide, gender persecution, refugee issues, and disability rights. exergueetdes réalisationsimportantesau niveau internationalàtraversles Nations Unies sont examinées. Tout comme le mouvement des femmes pour les droits humains, la question des droits des handicapésémergeaussidelapériphérie pourêtreintégrée audiscoursdominantdes droitsdel'homme. Enmatièredeprotection, la législation et la politique canadiennes enverslespersonneshandicapéesontreflété ces développements. Cependant, pourles réfugiés handicapés, les gains semblent infimes. En fait, tout en proclamantbien hautpourlebénéfice desesproprescitoyens larhétoriquesurlesdroitsdeshandicapés, leCanadaamisenoeuvredespolitiquesqui sont discriminatoires envers les réfugiés handicapés. Lescritèresutilisésoutremer parleCanadapourlasélectiondecandidats àl'établissementsontencontradictionavec sespositionsdomestiquesetintemationales sur les droits del'homme des personnes handioapées.

\section{Introduction}

There is a new group on the rights horizon, the disability rights movement. The disability rights movement has been active at both the domestic and international levels, culminating in significant achievements at the international level through the United Nations (UN). In much the same way that women's human rights emerged from the margins and moved into the mainstream of human rights discourse, so too are the rights of persons with disabilities. National legislation and international instruments, principles and declarations are first steps towards the removal of attitudinal, physical, social and economic barriers which have historically excluded disabled persons from mainstream society. Canada's legislation and policies towards persons with disabilities have mirrored these developments in providing protection.

However, for refugees with disabilities the protection is not so clear. For them, thebenefits seem minimal. Infact, while proclaiming the rhetoric of disability rights to its own citizens, Canada has implemented policies which are discriminatory towards refugees with disabilities. This paper will provide a preliminary survey of the evolution and positioning of disability rights as human rights and the discrepancy between Canadian resettlement policies with regard to refugees and Canada's rhetoric with regard to persons with disabilities.

Disabled people are invisible and suffer from "apartheid" (Frankel 1998:3). They are a challenge to the overriding ableism of the dominant group, whether in the North or in the South. According to the UN, there are over 500 million persons with disabilities worldwide $10 \%$ of the population). Approximately $66 \%$ of them live in the developing world. For those countries affected by landmines, this number can increase exponentially. Approximately $80 \%$ of the disabled live in isolated rural areas where services are unavailable. In addition, attitudinal, social, physical and economic barriers result in the de facto segregation of much of this population. Many will live out their lives in isolation and poverty (United Nations 2000b).

\section{Disability Rights Are Human} Rights: Domestic Framework

A very brief survey of some of the disability rights organizations and their achievements in the U.S. and Canada reveal that significant changes have occurred. However, the survey also reveals that these changes are the result of sustained lobbying by disability rights organizations. Achievements are wrested from often reluctant governments who view accessibility for disabled persons from a cost-benefit analysis. The result is a neurotic dichotomy from governments with, on 
the one hand, rhetoric and promises regarding disability rights and, on the other hand, reluctant action. What clearly emerges is that disability rights activists explicitly view their struggle as a human rights issue.

In the U.S., the first federal disability rights legislation was passed in 1968 , mandating that all federal buildings and facilities be accessible to the disabled. During the 1970s, the first legal advocacy centre was formed at the University of Notre Dame and the first legislation confronting discrimination against persons with disabilities was passed. Other victories in areas such as access to transportation, deinstitutionalization, education and employment soon followed. However, the most significant legislation is the Americans with Disabilities Act of 1990, containing the most comprehensive disability legislation in history (Pelka 1997:348359).

In Canada, specifically Ontario, the Ontarians with Disabilities Act (ODA) Committee was formed to lobby for the passage of laws which would achieve a barrier-free society for persons with disabilities. Voluntary in nature, the ODA Committee is a broad-based coalition of disability rights organizations and individuals who have been instrumental in focusing attention on the lack of such legislation in Ontario and in lobbying the government to remedy the situation.

In 1995, during the provincial election campaign, Conservative leader Mike Harris promised in writing to enact an Ontarians with Disabilities Act (ODA) in his government's first term of office (Harris 1995:1). In 1996 and 1998, the Ontario Legislature unanimously passed two resolutions calling on the Harris government to enact an ODA and to work with the ODA Committee in the formulation of such legislation (Ontario Legislature 1996 and 1998a). The ODA, Bill 83, was finally introduced in the Ontario Legislature in 1998.

Despite its purported intent to "improve the identification, removal and prevention of barriers faced by persons with disabilities" (Ontario Legislature 1998b), the Act was severely criticized bytheODACommittee. One of the short- est bills in the Legislature's history (only three pages), the ODA's provisions applied only to the Ontario Government, guaranteed no rights, provided no penalties and contained no time lines for the removal or prevention of barriers. In addition, it forbade the use of court proceedings to enforce its provisions. Finally, the ODA did not require governmentalministries to consult with disability rights groups, or anyone else, in the development of their respective plans of action (ODA Committee 1998). Three and a half weeks after its introduction the bill was left to die on the table when the Ontario Legislature rose for the holidays (ODA Committee 1999), leaving a gap in legislation which is still present. Since then, the Ontario Legislature, through a third unanimous resolution, has once more called upon the government to enact an ODA, to no avail (Ontario Legislature 1999).

At the national level, the DisAbled Women's Network (DAWN) was founded in Winnipeg, Manitoba in 1987. Featuring chapters in most of the provinces and in other countries as well, DAWN is the largest feminist cross-disability rights group in North America. DAWN has contributed to research into the areas of sexual and physical violence against women with disabilities. One of its most significant accomplishments was the publication of a manual on how to make women's shelters and rape crisis centers accessible, one which has become an industry standard in both Canada and the U.S. (Pelka 1997:105).

Other disability rights organizations include the Canadian Disability Rights Council (CDRC), also based in Winnipeg. A national advocacy organization for the advancement of Canadians with disabilities, CDRC's work focused on disability rights and the law. It called for amendments to Canada's Immigration Act which would end discriminatory policies and practices towards disabled persons seeking to come to Canada. The CDRC also undertook research and intervened in legal challenges (CDRC 1982:12-16,i). However, having contributed significantly to these issues in the 1980s and early 1990s, the CDRC has since dissolved.

But other disability rights organizations continue to advocate for the full participation in society of disabled persons. Formed in 1976, the Council of Canadians with Disabilities (CCD) is a national cross-disability advocacy organization with many member groups. The CCD has been active in Constitutional debates, employment equity, transportation and education (CCD 2000). Clearly viewing its mission within a human rights framework, the CCD has a Human Rights Committee which recently submitted a brief to amend the Canadian Human Rights Act to the Human Rights Act Review Panel. For more than 20 years the Canadian Human Rights Act has included disability yet CCD's analysis of the legislation concludes that the Act has failed to accomplish its goals since barriers continue to exist while new ones are created (CCD 1999).

During this time period, a landmark development for disability rights occurred in Canada. In 1982, the Constitution Act was passed, containing a package of reforms which included the Canadian Charter of Rights and Freedoms (the Charter). Initially, the disabled were not included in the draft version of the legislation and this exclusion was highlighted by the CCD. The inclusion of disability within the equality provisions of the Charter was achieved through intense lobbying by disability rights organizations. Entering into force three years later in order to allow governments to align existing laws with its equality provisions, Section 15 of the Charter states:

Every individual is equal before and under the law and has the right to the equal protection and equal benefit of the law without discrimination and, in particular, without discrimination based on race, national or ethnic origin, colour, religion, sex, age or mental or physical disability [emphasis added]

Section 15 has engendered a whole host of legal challenges from equality seeking groups, including the disabled community. Currently, in the absence of 
the CDRC, Charter litigation is being carried out by the CCD. Interventions at the Supreme Court level have been initiated regarding issues such as assisted suicide (Rodriguez case), privacy (Conway case), accommodation (Bhinder case) and murder (the controversial Latimer case) (CCD 2000). Currently, and sadly, the CCD is not undertaking research or advocacy in connection with refugee or immigration issues.

\section{International Framework}

At the international level, DisabledPeoples International (DPI), founded in 1981 in Winnipeg, is a global network of approximately 110 cross-disability organizations. Members of DPI include DAWN andCCD, with the latter participating in the founding of the organization(CCD 2000). The network provides a disability rights perspective and has advisory status with the International Labor Organization (Pelka 1997:102 103;Driedger 1989:94). In addition,DPI has consultative status with UNESCO, the UN Human Rights Sub-Commission, and ECOSOC, with the latter encompassing UN agencies such as UNICEF and UNHCR. Since 1981 DPI has made strong representations at the UN. A key issue which the network has promoted is disability definitions, specifically the rejection of the medical definition of disability and the promotion of the notion that physical and social barriers are the true disabling factors in the lives of disabled persons (Driedger 1989:94-95). In close cooperation with the UN, they have achieved stunning success, despite occasional setbacks.

The UN has clearly and squarely positioned disability rights within a human rights framework. Citing the UN Charter and the Universal Declaration of Human Rights as the fundamental and normative basis for the evolution of international norms and standards pertaining to persons with disabilities. In fact, the organization states that "in light of other relevant international norms, promotion of the human rights of persons with disabilities represents an integral part of the purposes of the Organisation"(United Nations 1999b).
However, it is important to note that protection without enforcement is not enough. Reporting to the UN Human Rights Commission in 1998, the UN Special Rapporteur on Disability stated that "when viewed through a disability perspective, there is little compliance with the Universal Declaration of $\mathrm{Hu}$ man Rights" (Lindqvist 1998:3).

Over 25 years ago, the General Assembly adopted two international instruments which specifically addressed persons with disabilities. The Declaration on the Rights of Mentally Retarded Persons was adopted by the General Assembly in 1971 and the Declaration on the Rights of Disabled Persons was similarly adopted in 1974 (United Nations 1999b). Both instruments were acceded to by Canada (CCD etal 1994). TheConvention of the Rights of the Child is the first international treaty which specifically recognizes the rights of disabled children and enshrines those rights within international law (United Nations 1999b).

In 1976, the UN General Assembly proclaimed 1981 as the International Year of Disabled Persons, with the theme "Full Participation and Equality". Mirroring the theme, a plan of action was called for which emphasized the equalization of opportunities, rehabilitation and prevention. What emerged was the realization that social attitudes frame the image of persons with disabilities. Attitudinal barriers bar the realization of full participation in and equality within society for the disabled (United Nations 1999b).

Originally intended for adoption in 1981 during the International Year, the World Programme of Action Concerning Disabled Persons (WPA) faced its own challenges. The first draft of the WPA was prepared in 1980 and emphasized medical rehabilitation, reinforcing the medical model of disability which views the disabled as passive recipients of care. The document was criticized by the individuals and organizations who would form DPI one year later. The Canadian chairperson of the newly formed DPI represented the infant organization as a member of the Canadian delegation on the WPA draft- ing committee, and was instrumental in convincing the committee to discard the draft WPA. The twenty-three country committee decided to re-draft the WPA, which was adopted by the UN General Assembly in 1982, one year behind schedule.

The new document was based on the model of full participation of disabled persons and emphasized consultation with disability organizations (Driedger 1989:98). It was also the first international instrument to address the advancement of persons with disabilities within a development framework, with equality as a main goal (United Nations 1999 b). Paragraph 18 states that "the WPA is based on the principles of human rights, full participation, self-determination, integration into society and equalization of opportunity, while the traditional model was based on segregation, institutionalization, and professional control" (cited in Driedger 1989:98). Initially established to commemorate the adoption of the WPA, December 3 is now observed annually by the UN as the International Day of Disabled Persons (United Nations 1999a; 2000). Clearly, DPI influenced both the re-drafting and the acceptance of the WPA at the UN.

As a means to further implement the WPA, the period 1983 to 1992 was declared by the General Assembly as the UN Decade of Disabled Persons. During the midpoint of the Decade, in 1987, DPI representatives, disenchanted with the low implementation rate of the WPA by many countries (many of whom had not even recognized the Decade of Disabled Persons), stormed the Third Committee of the UNGeneral Assembly. As the visitors gallery was physically inaccessible, DPI members proceeded onto the floor of the meeting and, over a three day period, lobbied government representatives to adopt a resolution calling for greater recognition of the Decade. Such a resolution was adopted (Driedger 1989:101-102).

Outcomes of the Decade included the Tallinn Guidelines for Action on $\mathrm{Hu}$ man Resources Development in the Field ofDisability, which were adopted by the General Assembly in 1989. Pro- 
duced by an interregional expert group, the Guidelines "provide a strategic frameworkfor promoting participation, training and employment of persons with disabilities" (United Nations 1999b). The Principles for the Protection of Persons with Mental Illness for the Improvement of Mental Health Care were adopted by the General Assembly in 1991. The Principles outline and define the basic rights and freedoms of persons with mental disabilities at an international level (United Nations 1999b).

As an outcome of the Decade, the Standard Rules on the Equalization of Opportunities for Persons with Disabilities were adopted by the General Assembly in 1993. Containing twenty-two rules, they are intended to further equalization of opportunities by, for and with persons with disabilities. Although not legally binding, the Standard Rules include targets, implementation measures and monitoring mechanisms (United Nations 1999b). Again demonstrating leadership, Canada played a key role in the adoption of the Standard Rules (CCD et al 1994).

Through resolution 48/99, which calls for a "society for all by the year 2010," the General Assembly has created a time limit for the achievement of its goals with respect to persons with disabilities. To assist in the creation of an inclusive global society, the General Assembly endorsed in 1994 the Long term Strategy to Implement the World Programme of Action concerning Disabled Persons to the Year 2000 and Beyond. Outlining actions, targets, timeframes and support measures for governments, the Strategy covers a fifteen year period, 1995-2010 (United Nations 1999b).

Other formats used to address the situation of persons with disabilities are international conferences organized by the UN. In 1993, the World Conference on Human Rights adopted the Vienna Declaration and Programme of Action which contained a specific section on the rights of persons with disabilities. Similarly, the International Conference on Population and Devel- opment, through it Programme of Action, addressed disability issues in its chapter on the family. The Copenhagen Declaration on Social Development and Programme of Action of the World Summit for Social Development recognized and addressed the social isolation and economic marginalization of persons with disabilities in each of its three main chapters.

Addressing physical barriers, the Conference on Human Settlements (Habitat II), through the Istanbul Declaration on Human Settlements and the Habitat Agenda, cited as an objective the design and implementation of accessible standards for persons with disabilities. In 1995, the Fourth World Conference on Women, through the Beijing Declaration and Platform for Action, recognized the multiple barriers faced by women with disabilities within the areas of advancement and empowerment (United Nations 1999b). Ironically, the site of the NGO Forum of the latter conference was inaccessible to persons with disabilities, the program was not available in alternative format, and no sign language interpretation was provided (Boldt 1996).

The WPA included a section on the human rights of disabled people. This stimulated the appointment of $\mathrm{Mr}$. Leandro Despouy as the first UN Special Rapporteur on Disability. His study on human rights and disability sparked further activities including: a General Comment in 1994 by the Committee onEconomic, SocialandCultural Rights; increased attention to disabled children from the Committee on the Rights of the Child; attention to disabled women by the Commission on the Status of Women; and resolutions passed by the UNHuman Rights Committee on disability and human rights (Lindqvist 1998:4). In 1994, Mr. Bengt Lindqvist, who is blind (and the former vice-chairperson of DPI), was designated by the Secretary-General as UN Special Rapporteur on Disability of the Commission for Social Development. His duties include monitoringtheimplementation of the Standard Rules, maintaining a dialogue with States and NGOs and working closely with a Panel of Experts composed of representatives from international disability NGOs (United Nations 2000a).

As early as 1982, and as a result of the WPA, the UN Human Rights Commission was encouraged to consider violations of human rights which caused mental and physical disabilities, with a view to "taking appropriate ameliorative action" (United Nations 1982:9). Since 1993, the UNHuman Rights Commission has adopted over ten resolutions dealing with human rights and disability, some focusing specifically on children with disabilities. The Commission has also received the annual reports of the Special Rapporteur on Disability and considered his recommendations for the improvement of the human rights situation of persons with disabilities (please refer to website for individual resolutions and reports).

Past and future initiatives clearly indicate that disability rights are firmly positioned within the human rights framework. For example, with regard to the continued monitoring of the Standard Rules, suggestions have been made that a joint monitoring mechanism be established between the UN Commission for Social Development (which currently houses the Special Rapporteur on Disability) and the UN Human Rights Committee. In an attempt to reinforce the human rights of persons with disabilities, in 1988 and 1989, the Italian and Swedish governments proposed to the General Assembly a Convention on the Rights of Persons with Disabilities. While both proposals were rejected, there is current discussion on the elaboration of special disability protocols to be attached to the two main human rights conventions as an alternative to the adoption of a special convention. Adopting the latter plan would reinforce the mainstreaming of disability rights within the larger framework of human rights, thereby reinforcing integration versus segregation (Lindqvist 1999:4-5).

The developments at the UN level providemoral and political imperatives for governments to accede to principles of accommodation and integration of persons with disabilities. While not 
well resourced and without enforcementmechanisms, the UN's initiatives, in partnership with international disability NGOs such as DPI, provide disability rights activists with the tools to ensure the removal of systemic and attitudinal barriers towards persons with disabilities. Those same tools have been used successfully by human rights activists for decades in what is known as the "shame game," highlighting the discrepancies between a government's practices and rhetoric.

\section{Refugees With Disabilities}

Issuing its ultimatum by dropping leaflets over the city of Grozny in Chechnya late last year, the Russian government instructed all inhabitants to leave the city by December 1999 in order to avoid being killed by the forthcoming bombardment (Amnesty International 1999:2). While many civilians fled, the most vulnerable could not: the elderly, the disabled and many of their caregivers, who are historically women. They had to endure a bombardment which would level the city.

For theover 500 million persons with disabilities worldwide $(10 \%$ of the population) (United Nations 2000b), fleeing armed conflict or persecution can become almost impossible. Many children and adults with mobility impairments are simply left behind by families who are forced to make terrible choices. Consequently, the number of persons with physical disabilities or serious medical conditions who are able toflee and reach refugee camps or countries of asylum will be less.

For refugee women with disabilities, the dual vulnerabilities of gender and disability can become a nightmare of exploitation and neglect. In the developing world, access to resources by women with disabilities are further limited. In societies in which a woman's power is often derived from her status as mother and wife, the social position of disabled women becomes more precarious due to the perception that they are unmarriageable. Moreover, with the majority of the world's disabled living in rural areas in which physical labour, often performed by women in the home and in the field, a disabled women is seen as inefficient and, therefore, of inferior value. Consequently, her status is diminished, leaving her even more vulnerable and stigmatized (CCD et al 1994).

For refugees with disabilities, resettlement to a country such as Canada can be the difference between life and death. Overseas resettlement is used as a vehicle to provide protection for the most vulnerable of refugees. Once identified by UNHCR, referrals are made to resettlement countries such as Canada. Referrals are accepted on the basis of their ability to pass Canada's selection criteria, at which point therefugees are transported to Canada as de facto refugees who are not required to go through the in-land determination process.

In determining the appropriateness of resettlement, UNHCR uses criteria to identify refugees in need of protection. However, prior to the promotion of resettlement, protection officers are instructed to explore local solutions while simultaneously assessing the feasibility of voluntary repatriation (UNHCR 1998a:1,3). UNHCR can refer refugees for resettlement on the basis of medical needs, which are assessed on a case-bycase basis. The agency has found that "the resettlement of persons with medical needs is challenging, and resettlement opportunities are limited" (UNHCR 1998a:8). Therefore, only cases with the most serious problems are addressed through resettlement. In selecting cases, a complex web of specific determination criteria are used, including barriers to well adjustment and satisfactory functioning presented by the country of asylum (UNHCR 1998a:8). In very rare cases, and only on a temporary basis, UNHCR may refer a refugee with a disability and/or medical needs for medical evacuation. However, once treatment is received or the medical crisis is over, the refugee is returned to the country of first asylum.

For UNHCR, those disabled refugees who are well-adjusted to their disability and are able to function at a satisfactory level within the country of asylum are not to be promoted for resettlement. This includes, for example, a refugee with a hearing impairment who has learned sign language and is able to work or benefit from training. Remedies for other forms of disabilities include the provision of prosthetics or hearing aids. "Only when such disabilities are untreatable locally, and when they seriously threaten the persons safety or quality of life, should resettlement be explored" (UNHCR 1998a:9).

Clearly following the medical model approach to disability, UNHCR's search for treatment reveals the erroneous belief that disability equals chronic illness. Moreover, the provision of prosthetics or hearing aids does not automatically ensure that the individual will be able to overcome cultural stigmatization related to disability and thereby survive economically or socially. Clearly, the use of the UN Standard Rules for the Equalization of Opportunities for Person with Disabilities are not being used in these assessments for referral probably because of the reluctance of resettlement countries to accept refugees with disabilities. For example, the UNHCR's projected resettlement needs in 1995 numbered 2,360 persons who were medically at risk/ physically disabled, and noted that few countries were responsive to such emergency cases (UNHCR 1994: 30,27).

With regard to overseas resettlement, Canada applies its own selection criteria. Approximately 10,000 refugees are resettled each year in Canada (Herringer 2000a:1), of whom 30-35\% are referred by UNHCR (Herringer 2000b:1). Tobe eligible for resettlement, individuals must be Convention Refugees seekingresettlement or be members of the Country of Asylum or Source Country class (called Humanitarian Designated Classes) (UNHCR 1998b:1).

However, the designated classes have proved to be cumbersome in nature. For example, flexibility in designating a geographical region as a Source Country Class is limited due to the presence of the Source Country Schedule, which requires a 4-6 months process to add a country to the Schedule. In the case of the Country of Asylum Class, all individuals selected under this designation must have a private 
sponsor (CIC 1999a:1-2). Increasingly, Canada has been criticized by both UNHCR and other resettlement countries for gaps in its resettlement programs, including: long processing times, too much selectivity and high refusal rates (Herringer 2000b:3).

To be accepted by Canada for overseas resettlement, refugees must pass a medical exam and criminal and security screenings. They mustalso have the potential to establish in Canada within one year, although future regulations will likely extend this period to 3 to 5 years (Cassasola 2000:8; CIC 1999b:1). In assessing the latter, visa officers consider language ability, age, education, work experience, family size and adaptability (CIC 1999b:1). For refugees with disabilities, the perceptions, and misperceptions, regarding their ability to establish, particularly in connection with employment, can simply eliminate them from consideration. In an industrialized country such as Canada, one who played a key role in the passage of the UNStandard Rules on the Equalization of Opportunities for Persons with Disabilities, the Canadian Human Rights Commission has found that "in no sector have employers fully met their commitments on increasing employment opportunities for people with disabilities" (CHRC 1998). Clearly, the focus of attention should be the barriers within society rather than the disabled individual.

With regard to the medical in/admissibility criteria, these are divided into two main classifications: a) contagious diseases and b) disorders, disability or other health impairments. Conditional acceptance is offered to those whose disability or health impairment will pose minimal demands upon health care or social services. Moreover, medical admissibility on this basis is only valid for twelve months, then the medical examination must be repeated. Refugees with a disability or health impairment which is likely to cause demands on the health care or social services system are deemed medically inadmissible. However, should their condition respond to treatment they will be considered for future admission (at which time they must be medically examined again). Refugees with a disability or health impairment which causes demands tobe placed on the health care or social services system and whose condition in unlikely to respond to treatment are deemed medically inadmissible(RSTP 2000:31).

In 1997 and 1998, the total number of refugees found to be medically inadmissible for overseas resettlement were less than $1 \%$ ( 85 and 68 were rejected in 1997 and 1998 , respectively). In 1999 , that figure climbed to just over 1\%, with 99 rejected applicants (including principal applicant and dependents). These statistics do not differentiate on the basis of inadmissibility, that is those deemed inadmissible on the basis of excessive demand and on the basis of a danger to public health (Herringer 2000a:1).

However, the expanded category of special needs constituted approximately $10 \%$ of the total number of refugees accepted for resettlement. These include women at risk, urgent protection cases, unaccompanied minors, elderly refugees and relatives, victims of trauma and torture and other vulnerable cases (Herringer 2000a:2). With a figure of approximately 10,000 refugees resettled from overseas, those with special needs, as outlined above, constitute approximately 1000 individuals. What is not clear is what component of these acceptance figures are refugees with disabilities and/or medical needs.

Data regarding the number of applicants with disabilities that are accepted into Canada are not readily available. As well, statistics regarding those referred by UNHCR to Canada are also not available. However, one factor which clearly needs to be considered is self-censorship on the part of UNHCR. Being fully aware of Canada's selection criteria in connection with overseas resettlement, UNHCR referrals to Canada of refugees with medical needs or with disabilities will likely be curtailed, thereby reducing the number of rejections issued by Canada by virtue of declining medical referrals from UNHCR. Moreover, UNHCR's self-censorship can result in two outcomes: such cases will be referred to other resettlement countries without stringent medical inadmissibility criteria or they will not be referred at all. Without the statistics, measuring the impact at this level is next to impossible.

However, there are alternative ways for refugees with disabilities to be considered. Two vehicles which can be used to resettle refugees with disabilities are the private sponsorship and the Joint Assistance Sponsorship (JAS) programs. With JAS the responsibilities of sponsorship are shared by the government and the private sponsors for up to twoyears. The government assumes the financial aspects of responsibility while the private sponsors provide assistance to ensure integration of the refugee (UNHCR 1998b:9; CIC 2000:54, 56-57). However, provincial approval must still be sought even when using the sponsorship vehicles. In the case of Quebec, the JAS program is exclusively for refugees who have special needs, including those with a physical disability or who require medical care (CIC 2000a:62). However, lack of data disallows an analysis of these systems at the present time.

In very limited cases, whereby a refugee fails to pass the medical exam, a Minister's Permit may be issued on humanitarian and compassionate grounds. This would allow entry into Canada despite the medical inadmissibility of the refugee. However, since health and social services are the responsibility of the provincial governments, the concurrence of the province in question is required before admission can be granted. This is seen as essential because "refugees who are medically inadmissible to Canada may need costly treatment". Canada therefore "recommend[s] that only serious medical cases with close family ties to Canada be referred" (UNHCR 1998b:4). Most provinces have medical review committees which meet periodically to render decisions regarding the acceptance of a medically inadmissible refugee on a Minister's Permit. The decision-making process is complex and can at times be lengthy (CIC 2000a:43). However, Ontario and Brit- 
ish Columbia do not have review boards but consider such cases on an ad hoc basis.

In 1999, 195 Minister's Permits were issued to persons overseas who were deemed to be medically inadmissible. The figures make no distinction between those who were initially rejected on the basis of their posing a threat to public health and those who may incur excessive cost to the health and social services systems on the basis of disability. In contrast, over 1300 Minister's Permits were issued to persons overseas who had been convicted either in or out of Canada of a punishable offence. Clearly, the government views this category as having more potential than individuals with disabilities. Moreover, over 8500 permits were granted to persons under what appears to be a "catch-all" category (persons who do not comply with any of the conditions of the Act), yet it is impossible to assess whether any of these consisted of refugees with disabilities (CIC 2000b).

In applying these medical in/admissibility tests, Canada is subscribing to the notion that persons with disabilities are a burden to both the health care and social service systems. The excessive demands anticipated on these services by persons with disabilities reinforce negative stereotypes of the disabled as a drain on resources, resources which are principally intended for the able bodied. Instead of viewing persons with disabilities as an investment and not as an expense, Canada is assessing their value in terms of costs which is only one half of a cost/benefit analysis at that (CDRC 1982:18).

By applying a medical model approach, Canada, like UNHCR, attempts to diagnose the disability and then apply a prognosis, which for many is inapplicable. For example, many disabilities are not amenable to "treatment" such as developmental disabilities, blindness, deafness or mobility impairments (CDRC 1982:17). However, with the removal of barriers many individuals have been able to achieve self-sufficiency and political power as exemplified by the rise of disability rights organizations in Canada. This exami- nation reveals that two systems exist for the processing of refugees with disabilities - formal (overseas selection criteria) and informal (Minister's Permits) - with the latter designed to circumvent the former in an attempt to assist those refugees who are deemed medically inadmissible.

The lack of research into the area of refugees, disability and human rights is palpable and mirrors the historical invisibility of the disabled. When one considers the ability of refugees with disabilities to flee, their likelihood of surviving the flight and the decreasing chances of their being resettled, one can clearly see the outline of a bottleneck.

\section{Conclusion}

This article constitutes a preliminary survey of the convergence of disability rights with human rights and Canada's selection criteria for overseas resettlement. What is clear is that the deep-rooted misperceptions and assumptions regarding the lack of potential surrounding persons with disabilities survives despite the rhetoric of a developed country such as Canada. While recent significant achievements are attempting to promote the view that persons with disabilities are assets rather than liabilities, continued discriminatory policies and practices, such as Canada's resettlement selection criteria, simply reinforce old prejudices. Clearly, Canada's selection criteria is at odds with its domestic and international positions regarding the human rights of persons with disabilities. In fact, it is questionable whether the Immigration Act meets the equality provisions within the Charter or international standards as outlined by the UN.

While Bill C-31 ${ }^{1}$ promises regulations which will remove medical inadmissibility "on the basis of excessive medical demand" (Cassasola 2000:8), the new regulations will have to be carefully analyzed prior to declaringa victory for disability rights. The production of data relating to the acceptance of refugees with disabilities will be the final arbiter on whether Canada is aligning its practices with its rhetoric.

-

\section{Note}

1. Consultation processes in support of current government reform initiatives haveresulted in the issuance of key documents: Not Just Numbers: A Canadian Framework for Future Immigration and Building on a Strong Foundation for the $21^{\text {st }}$ Century: New Directions for Immigration and Refugee Policy and Legislation. While the latter report promotes a more responsive overseas resettlement program, it did not recommend the relaxation of the medical in/admissibility criteria. In contrast, the former report calls for clearer definitions regarding the concept of "excessive costs" as an assessment criteria in medical in/ admissibility cases (Legislative Review Advisory Group 1997).

\section{References}

Amnesty International. (1999). "Chechen Republic: Amnesty International Sends Human Rights Day Appeal to the UN Security Council", News Service 233/99, AI INDEX: EUR 46/44/99, 10 December 1999.

Boldt, Catherine. (1996). International Women's Conference, Report to the International Development Committee of the Council for Canadians with Disabilities, January 1996, URL:http:// www.pcs.mb.ca/ ccd/devjan96.html, viewed August 9, 2000.

Canadian Disability Rights Council (CDRC). (1982). Final Brief on the Proposed Amendments in Bill C-86 to Sections 19(1)(a) and (b) of the Immigration Act, prepared by Sandra A. Goundry, September 19, 1982, Winnipeg, Manitoba.

Canadian Human Rights Commission (CHRC). (1998). "Disability" in ANNUAL REPORT 1998, House of Commons, URL: http://www.chrc-ccdp.ca/ ar-ra/ar98-ra98/table.aspl=e, August 2, 2000.

Cassasola, Michael. (2000). "Resettlement in Bill C-31" in Refugee Update, Issue No. 40, Toronto, Summer 2000.

Citizenship and Immigration Canada (CIC). (2000a). "Chapter 4: Overseas Selection and Processing of Convention Refugees Seeking Resettlement and Members of the Humanitarian Designated Classes" in Overseas Processing Manual, URL: http:/ /www.cic.gc.ca/manuals/english/ OP-e/index.html, viewed August 2, 2000.

Citizenship and Immigration Canada (CIC). (2000b). "Annual Report to Parliament on Minister's Permits Issued in 1999", URL: 
http://www.cic.gc.ca/english/pub/ permits99e.html, viewed September 15, 2000.

Citizenship and Immigration Canada (CIC). (1999a). "Selection Criteria", Refugee Resettlement Model Project Profile, File No. 4665-5-9/SEL, October 20, 1999, URL: http://www.cic.gc.ca/ref-protection/ infoc. RM/proj-profiles_e/SELECTIONCRITERIA.htm, printed August 2, 2000.

Citizenship and Immigration Canada (CIC). (1999b). "Eligibility Criteria", Refugee Resettlement Model Project Profile, File No. 4668-5-9/ELI, September 21, 1999, URL: http://www.cic.gc.ca/ref-protection/ infoc../proj-profiles_e/ELIGIBILITYCRITERIA.htm, printed August 2, 2000.

Council of Canadians with Disabilities (CCD). (2000). Examples of CCD Actions, URL: http://www.pcs.mb.ca/ ccd/, viewed August 9, 2000.

Council of Canadians with Disabilities (CCD). (1999). Taking the Lead: Council of Canadians with Disabilities Proposals for Amending the Canadian Human Rights Act, Submission to Canadian Human Rights Act Review Panel, October, 1999, URL: http://www.pcs.mb.ca/ ccd/ archcc 5.html, viewed August 9, 2000.

Council of Canadians with Disabilities (CCD), Manitoba League of the Physically Handicapped and Disabled Peoples' International. (1994). Disabled People \& Foreign Policy:aCallFor Inclusion Brief to TheSpecial Joint Committee Reviewing Canadian Foreign Policy, May 1994, URL: http:// www.pcs. mb.ca/ ccd/forpol.html, viewed August 9, 2000.

Driedger, Diane. (1989). "The Last Civil Rights Movement: Disabled Peoples" International, New York: St. Martin's Press.

Frankel, Susannah. (1998). "Able to be Beautiful", Fashion, The Daily Mail and Guardian (South Africa), September 10, 1998, URL: http://www.mg.co.za/mg/art/ the_rest/9809/980910-fashion.html, printed August 6, 2000.

Harris, Mike (1995). Letter dated to Mr. David Baker, Executive Director, Advocacy ResourceCentrefor the Handicapped and the Ontarians with Disabilities Act Committee, May 24, 1995, URL:http:// www.indie.ca/oda/letters/scan.html, viewed September 10, 2000.

Herringer, Rick. (2000a). Director, Resettlement, Refugees Branch, Citizenship and
Immigration Canada, August 22, 2000, correspondence with the author.

Herringer, Rick. (2000b). "Opening Remarks, Tripartite Consultations", Geneva, July 2000, delivered by Rick Herringer, Director, ResettlementDivision, Citizenshipand Immigration Canada, URL: http:// www.cic. Gc.ca/ref-protection/ Infocentre/RRM/tripartite/ Tripartite_e.htm, viewed August 2, 2000.

Legislative Review Advisory Group. (1997). Not Just Numbers: A Canadian FrameworkFuture Immigration, Minister of Public Works and Government Services Canada 1997, Cat. No.: Ci63-21/1998E, URL: http://www.cic.gc.ca/english/ about/policy/lrag/emain.html

Lindqvist, Bengt. (1999). Promotion of Disability Policy Within the UN System After the Year 2000, Discussion Paper, UN Special Rapporteur on Disability, March 28, 1999, URL: http://www.gladnet.org/ glad mail/1999/30-s pecialrapporteur.htm, printed June 19, 2000.

Lindqvist, Bengt. (1998). Statement by Mr. Bengt Lindqvist, Special Rapporteur of the UNCommission for Social Development, March/April 1998, UN Commission on Human Rights, $\mathbf{5 4}^{\text {th }}$ Session, Agenda Item 15, URL: http:// www.independentliving.org/ STANDARDRULES/Lindqvist804.html, printed June 19, 2000.

Ontarians with Disabilities Act (ODA) Committee (1999). Press Release, Harris Government's Disability Bill Dies - 1.5 Million Ontarians with Disabilities More Frustrated than Ever, January 6, 1999, URL: h t t p://www.indie.ca/oda/ press22.html, viewed September 10, 2000.

Ontarians with Disabilities Act (ODA) Committee (1998). ODA Committee Quick Analysis of Ontario Government Bill 83 which received First Reading in the Ontario Legislature on Monday, November 23, 1998, URL: http://www.indie.ca/oda/ do-nothing.html, viewed September 10, 2000.

Ontario Legislature (1999). ODA Resolution Unanimously Passed, November 23, 1999, URL: http:// www.indie.ca/oda/ hansard39.html, viewed September 10, 2000.

Ontario Legislature (1998a). ODA Resolution Unanimously Passed, October 29, 1998, URL: http://www.indie.ca/ oda/ oct-resolution.html, viewed September 10, 2000.

Ontario Legislature (1998b). Ontarians with Disabilities Act, Bill 83. An Act to Improve the Identification

Removal and Prevention of Barriers Faced by Persons with Disabilities. Introduced November 23, 1998, URL: http:// www.indie.ca/oda/bill83.html, viewed September 10,2000.

Ontario Legislature (1996). ODA Resolution Unanimously Passed, May 16, 1996, URL: http://www.indie.ca/ oda/2.html, viewed September 10, 2000.

Pelka, Fred. (1997). The ABC-CLIOCompanion to The Disability Rights Movement Santa Barbara, California: ABC-CLIO, Inc, 1997.

Refugee Sponsorship Training Program (RSTP). (2000). Sponsorship Agreement Holder's Manual,2000, Toronto (unpublished).

Stubbs, Sue. (1995). Disabled Refugees, Draft Notes, Save the Children, 1995, URL: http://www.eenet.org.uk.scf disrefuge.htm, viewed June 19, 2000.

United Nations. (2000a). The UN and Persons with Disabilities: United Nations Commitment to Advancement of the Status of Persons with Disabilities, URL: http:// www.un.org/esa/socdev/enable/ disun.htm, viewed August 13, 2000.

United Nations. (2000b). The United Nations and Disabled Persons: The First 50 Years, URL:http://www.un.org/ esa/socdev/ enable/dis50y00.htm, viewed August 9, 2000.

United Nations. (1999a). International Day of Disabled Persons: 3 December 1999,URL: http://www.un.org/ esa/socdev/enable/disid99.htm, viewed August 9, 2000.

United Nations. (1999b). Compilation of International Norms and Standards Relating to Disability, Draft Release 21 May 1999, URL: http://www.un.org/esa/socdev/ enable/discom02.htm, viewed August 9, 2000.

United Nations. (1982). World Programme of Action Concerning Disabled Persons, URL:http://www.un.org/ esa/socdev/ enable/diswpa09.htm\#Human rights, viewed August 9, 2000.

United Nations. (undated). The International Year of Disabled Persons 1981, URL: http://www.un.org/ esa/socdev/enable/disiydp.htm, viewed August 9, 2000.

UNHCR. (1998a). "UNHCR Criteria for Determining Resettlement as the Appropriate Solution" in The UNHCR Resettlement Handbook, April 1998.

UNHCR. (1998b). "Canada: by the Government of Canada" in The UNHCR Resettlement Handbook, April 1998.

UNHCR. (1994). Assessment of Global Resettlement Needs for Refugees in 1995 UNHCR Resettlement Section, Geneva, December 1994. $\square$

\section{Feedback? Questions? Remarks? We welcome them all. Send to: refuge@yorku.ca}

